\title{
Correction to: Characterization, antioxidant, and cytotoxic effects of some Egyptian wild plant extracts
}

\author{
Thoria A. Diab', Thoria Donia ${ }^{1}$ and Khalil M. Saad-Allah ${ }^{2^{*}}$
}

Correction to: Beni-Suef Univ J Basic Appl Sci (2021) 10:13

https://doi.org/10.1186/s43088-021-00103-0

Following the publication of the original article [1] the authors requested to remove the middle initial from the second author's name.

The author's name 'Thoria K. Donia' has now been updated to 'Thoria Donia' in the original article and the same is included in the author list of this Correction.

\section{Author details}

'Biochemistry Division, Chemistry Department, Faculty of Science, Tanta

University, Tanta 31527, Egypt. ${ }^{2}$ Botany Department, Faculty of Science, Tanta

University, Tanta 31527, Egypt.

Published online: 22 March 2021

\section{Reference}

1. Diab TA et al (2021) Characterization, antioxidant, and cytotoxic effects of some Egyptian wild plant extracts. Beni-Suef Univ J Basic Appl Sci 10:13 https://doi.org/10.1186/s43088-021-00103-0

* Correspondence: khalil.saadallah@science.tanta.edu.eg

${ }^{2}$ Botany Department, Faculty of Science, Tanta University, Tanta 31527, Egypt

Full list of author information is available at the end of the article

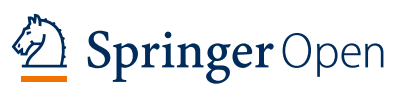

(c) The Author(s). 2021 Open Access This article is licensed under a Creative Commons Attribution 4.0 International License, which permits use, sharing, adaptation, distribution and reproduction in any medium or format, as long as you give appropriate credit to the original author(s) and the source, provide a link to the Creative Commons licence, and indicate if changes were made. The images or other third party material in this article are included in the article's Creative Commons licence, unless indicated otherwise in a credit line to the material. If material is not included in the article's Creative Commons licence and your intended use is not permitted by statutory regulation or exceeds the permitted use, you will need to obtain permission directly from the copyright holder. To view a copy of this licence, visit http://creativecommons.org/licenses/by/4.0/. 